\title{
Psephology and pulmonology
}

\author{
Maeve Barry \\ Affiliations: European Respiratory Society, EU Affairs, Brussels, Belgium. \\ Correspondence: Maeve Barry, ERS Office, EU Affairs, 49-51 Rue de Treves, 1040, Brussels, Belgium. \\ E-mail: maeve.barrydersnet.org
}

@ERSpublications

Science and politics can't be viewed in isolation: ERS brings both together through ongoing advocacy activities http://ow.ly/yUrHn

"Just because you do not take an interest in politics does not mean politics won't take an interest in you"

Pericles

Europe, in its various forms, has been voting since antiquity. From the golden Athenian age of Pericles to the austerity age of modern Europe, elections and their results continue to be anticipated, scrutinised and debated. This editorial focuses on the recent exercise from May22-25, 2014, when citizens of the European Union (EU) voted to elect the 8th legislature of the European Parliament.

Psephology is the "the statistical study of elections and trends in voting" as defined by the Oxford English Dictionary (www.oed.com). These trends show that in May 2014, 43\% of EU voters turned out to "act, react, and impact" [1]. Although there was an improvement compared with previous turnouts, it seems Pericles' warning has still not been heeded by the majority of EU voters. By contrast, those who did vote have already shaped the policies of the European Parliament for the coming years, which include those that affect pulmonology.

According to the European Parliamentary Research Service, in the Parliament's last term (2009-2014), it held 2821 meetings, conducted more than 23500 votes, and adopted more than 19000 amendments whilst rejecting even more [2]. Hardly surprising, therefore, that the European Parliament is one of three main institutions within the EU that is involved in EU legislation. It has been directly elected since 1979, and on this occasion 751 Members of the European Parliament (MEPs) were elected.

These MEPs will, by now, have organised themselves according to political groups, rather than by country or by national party. Well established political groups include (from right to left): European Conservatives and Reformists (ECR), the European Peoples' Party (EPP), Alliance of Liberals and Democrats for Europe (ALDE), Socialists and Democrats (S\&D) and the Greens [3].

During this term, these MEPs will join specific committees such as the Environment, Public Health and Food Safety committee or the Industry, Research and Energy committee. There are 20 such Committees preparing, debating, and negotiating legislation on topics from agriculture to employment law to development assistance.

The main powers of the European Parliament can be summed up as the ability to accept, reject or amend draft legislation, budgetary oversight, and approval of the appointment of European Commissioners [4]. This, in a nutshell, is the task of those elected to represent the interests of 500 million citizens for the next 5 years. While the election results make interesting reading, they may not be as dramatic as reported.

Despite anticipated disarray, the largest parties remain the centre-right EPP followed by the centre-left S\&D.

Received: June 062014 | Accepted after revision: July 022014

Conflict of interest: M. Barry is an employee of the European Respiratory Society.

Copyright @ERS 2014 
Most attention is rightly focused on where new alliances can be made and lost. In particular, attention is on the remaining non-attached members [5] and newly elected members who, at the time of writing, had not expressed an affiliation to any of the political groups. The majority of these MEPs come from populist, extremist or Euro-sceptic parties from both the right and the left, hostile to the European project.

The issue of whether or not these Euro-sceptics form the different political groups matter greatly, as very practical issues such as group funds, allotted speaking time and committee positions depend on the potential size of a group; a minimum of $25 \mathrm{MEPs}$ from at least seven Member States are needed.

The result of this realignment is likely to manifest itself in a fenced-in middle ground. We are seeing a "grand coalition" working together. The EPP and S\&D together have enough seats to find a majority, and it is an even larger majority with ALDE on board. This will mean a conservative compromise approach. The large parties will be obliged to agree and so prevent themselves from tabling significant changes to legislation. A "no-go" area of parties or individuals will then emerge, largely ignored on the fringes. This would indeed be ironic given the supposed premise of a "protest vote" to send radicals from the left and right to shake up the establishment. The earthquakes reported at national levels may well remain as national responses to national issues, with no impact at a European level, as ultimately decisions could continue to be made without them.

In order to influence these decisions, the European Respiratory Society (ERS) deploys different approaches and methods to convey the respiratory community's messages. This is undertaken by: responding to public consultations; disseminating ERS policy positions to key decision makers; proposing amendments to legislation; organising events and campaigns to raise awareness; hosting ERS high-level policy events; and by securing speaking time for the ERS at various EU or World health Organization conferences on health [6]. As MEPs have the power to directly influence legislation ERS regularly seek to inform and convince MEPs of the need to support respiratory health in all policies [7].

Upcoming focus in the European Parliament will see:

- Healthy lungs for life. Raising awareness on lung health. The Healthy Lungs for Life campaign kicks off at the ERS International Congress in Munich (Germany) this month and will come to Brussels (Belgium) later in the year. The campaign in the European Parliament will include spirometry testing, an exhibition on lung health, in combination with focus on disease areas such as asthma, chronic obstructive pulmonary disease and lung cancer.

- Air quality. A specific legislative example concerns air quality legislation, which will set national industrial emission ceilings to be respected in all Member States. The ERS will be engaging with MEPs to raise awareness of the immense damage to lung health caused by air pollution, in order to ensure the strictest pollution limits possible [8].

- Tobacco. The ERS will continue to raise awareness and support among MEPs for strict tobacco control, including the introduction of plain packaging in all member states.

- Other topics. We can also expect other topics to arise as the European Parliament and new Commission become active. One potential topic is the "pharmaceutical package", a range of legislation governing medicines that could be amended during the next 5 years [9].

The last European Parliament elections were held in 2009 and since then Europe has been in a spiral of financial uncertainty, crisis and austerity. Despite this backdrop, health-related activities have remained on the agenda in Brussels. Concrete subjects such as medical device regulations, air quality limits, medical qualifications, research funding [10], and health promotion are all debated in Brussels, and all have an impact on ERS members [11]. The European Parliament is the most political of the institutions, and a key part of the decision making process. In these elections, votes were cast against "Europe" or the "the European Union". The reality is that these concepts are no more than the sum of their parts. While national governments may decry the interference of Brussels when politically expedient at national level, it remains a fact that it is the same national Member States who make up "Europe" who deliberate, negotiate and vote on every piece of legislation. National ministries sit around the negotiation tables and nationally elected MEPs represent citizens. ERS, in representing the wider pulmonology community will be working to influence these discussions, to represent our members, and to ultimately communicate the same message as Pericles, albeit for lung health.

\section{References}

European Parliament News. Act React Impact. www.europarl.europa.eu/news/en/news-room/content/20130905STO 18724/html/Act-React-Impact Date last accessed: June 6, 2014.

2 Members' Research Service. The European Parliament at a Glance. http://www.europarl.europa.eu/EPRS/140781REV1-

The-European-Parliament-2009-14-FINAL.pdf Date last accessed: 6/06/14. Date last updated: May 8, 2014. 
3 European Parliament. European Political Parties. http://www.elections2014.eu/en/european-political-parties Date last accessed June 6, 2014

4 European Parliament. Overview of Parliament and the 2014 Elections. http://www.elections2014.eu/en/press-kit/ content/20131112PKH24411/html/Overview-of-Parliament-and-the-2014-elections Date last accessed June 6, 2014.

5 European Parliament. Election Results. www.results-elections2014.eu/en/election-results-2014.html Date last accessed: July 8, 2014.

$6 \quad$ Sculier J-P. The European Lung Corner. Eur Respir J 2013; 42: 1433-1434.

7 Gibson GJ, Loddenkemper R, Lundbäck B, et al. Respiratory health and disease in Europe: the new European Lung White Book. Eur Respir J 2013; 42: 559-563.

8 Brunekreef B, Annesi-Maesano I, Ayres JG, et al. Ten principles for clean air. Eur Respir J 2012; 39: 525-528.

9 Directorate General Health \& Consumers. Pharmaceutical Package. http://ec.europa.eu/health/human-use/ package_en.htm Date last accessed: June 6, 2014.

10 Blasi F, Barry M, Ward B. Reaching the golden milestone. The 2013 ERS Dublin summit: preparing the road to Rome. Eur Respir J 2013; 42: 881-884.

11 Greer SL, Hervey TK, Mackenbach JP, et al. Health law and policy in the European Union. Lancet 2013; 381: 1135-1144. 